Natural Resources Conservation and Research (2019) Volume 2 doi:10.24294/nrcr.v2i1.775

\title{
Survival and Growth Performances of Clarias gariepinus (Teleotei: Clariidae) Fingerlings According to the Hormone Type in Recycled Water in South Cameroon
}

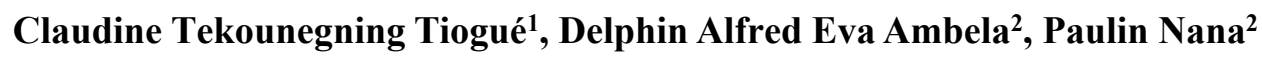

${ }^{1}$ Laboratory of Applied Ichthyology and Hydrobiology, School of Wood, Water and Natural Resources (SWWNR), Faculty of Agronomy and Agricultural Sciences (FAAS), the University of Dschang, P.O.Box 786, Ebolowa Antenna, Cameroon

${ }^{2}$ Institute of Fisheries and Aquatic Sciences of Yabassi, The University of Douala, P.O.Box 2701, Douala, Cameroon

\begin{abstract}
In order to compare effects of the of hormone type (Ovaprim and pituitary extracts) on survival and growth performances of African catfish Clarias gariepinus in recycled water; this study was conducted from April to August 2016, in the South Region Cameroon. The main results are as follows: The survival rate was higher in fish from females treated with pituitary extracts regardless of stage of development, without significant differences $(\mathrm{P}>0.05)$ between treatments. The fish treated with Ovaprim, expressed higher mass and linear growth performances than those treated with pituitary extracts, but not significantly $(\mathrm{P}>0.05)$ regardless the considered stage of development. The relative growth rate (TCR) showed that fish grow faster at the fry stage than at the juvenile stage for both hormone types. Growth was negative Allometric type and $\mathrm{K}$ factor was $<1$ during breeding. It was concluded that the use of the synthetic hormone is not essential for optimum production of Clarias gariepinus fingerlings.
\end{abstract}

Keywords: Hormone; Survival; Growth; Fingerlings; Clarias gariepinus

\section{Introduction}

Efforts to develop fish farming began in many African countries from the 1950s and 1960s ${ }^{[1]}$. In Cameroon, tilapia (Oreochromis niloticus), commun carp (Cyprinus carpio) and African catfish (Heterobranchus longifilis and Clarias gariepinus) are the most commonly farmed species ${ }^{[2]}$. Since the 1970 s, in association or in monoculture, Clarias gariepinus was considered as a fish of the future for the breeding thanks to its rusticity, his omnivorous diet, his rapid growth and his much appreciated flesh ${ }^{[3]}$. The large-scale production of Clarias gariepinus was until recently stagnant due to the lack of fry for the supply of production ponds. But artificial propagation techniques have been developed to mass produce juvenile ${ }^{[4-6]}$. In addition to solve the problem of lack of fry, 11 aquaculture stations are available to the state of Cameroon. These stations are located in Obili at Yaoundé, Logbaba at Douala, Maga in the Far-North region, Lagdo (Gounouko) in North region, Ngaoundere in Adamaoua, at Bambui-Nkwen and Bengwui (Ku-Bome) in North-West region, Koupa-Matapit at Foumban's IRAD in West region, Bertoua in the East region, Ebolowa in the South region and Kumba in South-West region. In parallel private fish farmers have built homemade hatcheries throughout the countr ${ }^{\mathrm{y}[7]}$. Moreover, information collected at the Ministry of Livestock, Fisheries and Animal Industries (MINEPIA) indicate that aquaculture is experiencing renewed vitality since the 2011 Agropastoral Comice in Ebolowa $^{[8]}$. A noticeable resurgence through the construction of an important value chain ${ }^{[9]}$.

However statistics show that in Cameroon, the supply of fish comes to $43 \%$ of fishing (22\% of inland fisheries, $21 \%$ of sea fisheries), $56.8 \%$ of imports and only $0.1 \%$ of fish farming, ie 1000 tonnes / year ${ }^{[10]}$. In view of this persistent situation, the state has by major structuring projects such as the Agropole project made available to fish farmers imported fish feeds and hormones, local food manufacturing facilities, modern hatcheries in recycled water or closed circuit, floating cages for juvenile rearing ${ }^{[9]}$. Cameroon counts for this, six centers of production of freshwater

Copyright (C) 2019 Claudine Tekounegning Tiogué et al.

doi: $10.24294 /$ nrcr.v2i1.775

EnPress Publisher LLC.This work is licensed under the Creative Commons Attribution-NonCommercial 4.0 International License (CC BY-NC 4.0).

http://creativecommons.org/licenses/ by/4.0/ 
fish in particular, the Littoral, the South, the Center, the North, the Far-North and Adamaoua ${ }^{[9]}$.

Thus, in the Littoral, East, Center and South of the country, closed-circuit hatcheries have exploded in recent years ${ }^{[11,12]}$. The breeding of Clarias gariepinus however still faces other challenges including, the lack of qualified personnel in aquaculture farms, not mastery of sophisticated infrastructure, low control larval rearing and optimal supply constraints ${ }^{[11]}$. Consequently the lack of fry is and remains the main cause of non-take-off of the cameroonian fish $^{[11,12]}$. The general objective of this work is then, the intensive production of fry in recycled water at the Akak Essatolo Fish Farm in Ebolowa, Cameroon. More specifically, it was a question of comparing the effects of two types of hormones on the survival and growth performance of Clarias gariepinus fry in this hatchery.

\section{Materiel and methods}

\subsection{Study area}

This study was conducted from April 1 to May 09, 2016 in the Akak Essatolo village, located in the Ebolowa 1

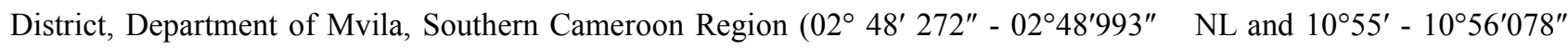
EL. The average altitude is $616 \mathrm{~m}$. The climate is equatorial hot and humid (Guinean), characterized by a short rainy season extending from mid-March to June; a short dry season that runs from July to August; a long rainy season from September to mid-November and a long dry season from mid-November to mid-March. The average temperature is $25^{\circ} \mathrm{C}$. Annual rainfall ranges from 1200 to $2000 \mathrm{~mm}$. It is thus included in the Cameroon agro-ecological zone $5 \mathrm{known}$ as bimodal rainfall ${ }^{[13]}$.

\subsection{Livestock infrastructure}

The assay was performed in a hatchery consists of a Surface building: $5 * 3 \mathrm{~m}^{2}$. It includes 06 closed-circuit containers with a volume of $0.4 \mathrm{~m}^{3}$ each, in which the reproduction, incubation and larval rearing operations are carried out. This device is fed by gravity by means of a castle supplied by a pump, having a flow rate of $4 \mathrm{~m}^{3} / \mathrm{h}$, itself fed by a well of $5 \mathrm{~m}$ deep.

\subsection{Animal material}

6 batches of $12000 \pm 58.65$ larvae of 3 days (D3) of Clarias gariepinus each, were used. These larvae were from an artificial female reproductive induced by Ovaprim hormones and pituitary extracts of males of C. gariepinus in the same farm ${ }^{[14]}$.

\subsection{Essay conduct and data collection}

The trial was conducted in two phases: fry and juvenile

\subsubsection{At the fry stage}

The larvae were distributed in triplicates by type of hormone in six closed-loop trays of $0.4 \mathrm{~m} 3$ at the rate of 0.04 larvae / 1 . water was renewed at $50 \% / 24 \mathrm{~h}$ in this system and the recirculation flow rate was $13.4 \mathrm{ml} / \mathrm{s}$. Animals' were fed 6 times daily ( $3 \mathrm{~h}$ am, $7 \mathrm{~h}$ am, $11 \mathrm{~h} \mathrm{am}, 3 \mathrm{~h} \mathrm{pm}, 7 \mathrm{~h}$ pm, and $11 \mathrm{pm}$ ) according to their average weight, using imported feeds whose size, brand, origin, manufacturer, rationing and protein rates are shown in Table $1^{[15]}$.

\begin{tabular}{|c|c|c|c|c|c|c|}
\hline \multirow{3}{*}{$\begin{array}{l}\text { Total weight } \\
\text { of fish (g) }\end{array}$} & \multicolumn{6}{|c|}{ Foods used Characteristics } \\
\hline & & & & Diameter & PL $(\%)$ & FR $(\%)$ \\
\hline & Name & Origin & Manufacturer & $(\mathrm{mm})$ & & \\
\hline 0,08 & Artemia Shell Free & Thailand & INVE LTD & 0.2 & 54 & 11 \\
\hline $0,08-0,2$ & Coppens & Germany & Coppens International & $0.2 / 0.3$ & 52 & 10 \\
\hline $0,2-0,5$ & Coppens & Germany & Coppens International & $0.3 / 0.5$ & 51 & 9 \\
\hline $0,5-2,6$ & Coppens & Germany & Coppens International & $0.5 / 0.8$ & 50 & $8,75-8$ \\
\hline $2,6-5$ & Coppens & Germany & Coppens International & $0.8 / 1.5$ & 45 & $7,75-7,5$ \\
\hline
\end{tabular}

FR: Feeding rate; PL: Protein levels (Source:[15]) 
Table 1. Characteristics of the different foods used during the test according to the total weight of C. gariepinus.

Every morning at 6 am to extract the organic waste, the bins were siphoned off using a plastic pipe $1 \mathrm{~cm}$ in diameter (bought on the local market). Then, every three days 50 larvae were caught at random from each batch using a net of $0.5 \mathrm{~mm}$ mesh, weighed on an electronic balance of accuracy $0.1 \mathrm{~g}$, CAMRY brand, and then placed quickly on millimeter paper for total length measurement. At the end of these measurements, the fish were returned to their respective bins. The test lasted 18 days (D21).

\subsubsection{Fingerlings stage}

At the $21^{\text {st }}$ day of breeding (D21), fry were calibrated and divided by type of hormone in 6 lots (triplicate) mean $8000 \pm 37.12$ each, then respective mean of 6 lots: $5000 \pm 30.23$ and $3000 \pm 23.60$ ( for each tray depending on the type of hormone) every two weeks (therefore at D35 and D49 following calibration) in the same infrastructures. At each calibration, the rest of the fish were stocked in cubitainers with $1 \mathrm{~m}^{3}$ volume, located outside the hatchery and intended for rearing, pre-enlargement and magnification. The fish were fed 4 times daily ( 7 am, 12 noon, $6 \mathrm{pm}$ and $10 \mathrm{pm}$ ) depending of average weight ( Table 1) until age 70 (D70). Weekly total lengths and average fish weights were collected in the same manner as at the fry stage. Such of physico-chemical parameters of water, as: temperature, $\mathrm{pH}$, Ammonium and Nitrites content were measured 4 times per day ( 7 am, 12 noon, 6 pm and 10 pm) by maxi-minima thermometer, PH-meter and kits respectively.

\subsection{Studied Characteristics}

\section{Survival rate}

The survival rate (SR) was calculated at the end of the first phase (D21), at each calibration and at the end of the rearing (D70) according to the formula:

$$
\mathrm{SR}(\%)=\frac{\mathrm{fN}}{\mathrm{iN}} \times 100 \text { where } \mathrm{fN} \text { is the final Number and iN the initial Number of fish }
$$

\section{Linear growth}

- Total length gain: TLG $(\mathrm{mm})=\mathrm{fTL}-\mathrm{iTL}$ with $\mathrm{fTL}=$ finale Total Length, and iTL $=$ initial Total Length.

- Average daily gain $(\mathrm{ADG})(\mathrm{mm} /$ day $)=\frac{(\mathrm{fTL}-\mathrm{iTL})}{\Delta \mathrm{t}}$ With $\Delta \mathrm{t}=$ the duration of the test

- $\quad$ Relative growth rate (RGR) $(\%)=\frac{\text { (fTL - iTL) }}{\text { iTL }} \mathrm{X} 100 \quad[16]$

- $\quad$ Specific growth rate (SGR) $(\% /$ day $)=\frac{(\ln \text { fL }-\ln \text { iTL })}{\Delta t} \times 100$ where $\mathrm{Ln}$ is the natural logarithm.

- Size variation coefficient or size heterogeneity: CV $(\%)=\frac{S x}{X} \quad$ where $S x=$ standard deviation, X: average of total lengths.

\section{Weight growth (or mass growth)}

- Final mean weight: $\mathrm{fmW}(\mathrm{g})=\frac{\mathrm{fB}}{\mathrm{fN}} \times 100$ where $\mathrm{fB}$ is final Biomass and $\mathrm{fN}$ the final Number of fish at the end of the test

- Mean weight gain : $\mathrm{mWG}(\mathrm{g})=\mathrm{fmW}-\mathrm{imW}$ with imW the initial mean Weight and fmW the final mean Weight

- $\quad$ Average daily gain: $\mathrm{ADG}(\mathrm{g} / \mathrm{day})=\frac{(\mathrm{fmW}-\mathrm{imW})}{\Delta \mathrm{t}}$ Where $\Delta \mathrm{t}$ is the test duration (days).

- $\quad$ Relative growth rate (SGR) was calculated according to the formula of [16]:

- $\quad$ RGR $(\%)=\frac{(\mathrm{fmW}-\mathrm{imW})}{\mathrm{imW}} \mathrm{X} 100$

- Specific growth rate: SGR $(\% /$ day $)=\frac{(\mathrm{fmW}-\mathrm{imW})}{\Delta \mathrm{t}} \times 100$ where $\mathrm{Ln}$ is the natural logarithm.

- The total weight / total length relationship was established in 70 days old (D70) juveniles according to the formula used by ${ }^{[17]}$ :

$\mathrm{TW}=\mathrm{a} \mathrm{TL}^{\mathrm{b}}$, with $\mathrm{a}=$ regression constant, $\mathrm{b}=$ regression coefficient, $\mathrm{TL}=$ Total Length $(\mathrm{cm})$ and $\mathrm{TW}=\mathrm{Total}$ Weight $(\mathrm{g})$.

- $\quad$ The condition factor $\mathrm{K}$ was calculated according to the formula used by ${ }^{[18]}$ :

$\mathrm{K}=100 \mathrm{X} \mathrm{TW} / \mathrm{TL}^{\mathrm{b}}$ with TW: Total Weight $(\mathrm{g})$, TL: Total Length $(\mathrm{cm})$ and $\mathrm{b}=$ slope of the regression line of the 
total weight-length relationship.

\subsection{Statistical analysis}

Descriptive statistics (mean, standard deviation, percentage ...) were used. The Student's t-test was used with the XLSTAT 2014 program, to compare different zootechnical parameters studied and the coefficient of allometry b to the isometric value $b=3$. The probability threshold was $5 \%$. The Excel 2013 spreadsheet was used for drawing graphs

\section{Results}

\subsection{Effect of hormone type on linear growth according to the developmental stage}

Table 2 presents the linear growth parameters of Clarias gariepinus at two stages of development depending on the type of hormone. It shows that fish from females treated by Ovaprim, compared to those of pituitary extracts, expressed the highest performance for all parameters regardless of the stage of development considered. However, this difference was not significant $(\mathrm{P}>0.05)$.

\begin{tabular}{lllll}
\hline \multirow{2}{*}{ Parameters } & \multicolumn{3}{l}{ Development Stages } & \multicolumn{2}{l}{ Figerlings (D21 - D70) } \\
\cline { 2 - 5 } & \multicolumn{2}{l}{ Fry (D3-D21) } & Ovaprim & Pituitary extracts \\
\cline { 2 - 4 } & Ovaprim & Pituitary extracts & $21,33 \pm 5,48^{\mathrm{a}}$ & $20,12 \pm 7,29^{\mathrm{a}}$ \\
\hline imL (mm) & $3,45 \pm 0,28^{\mathrm{a}}$ & $2,93 \pm 0,34^{\mathrm{a}}$ & $51,76 \pm 9,32^{\mathrm{a}}$ & $49,32 \pm 12,86^{\mathrm{a}}$ \\
fmL (mm) & $21,33 \pm 5,48^{\mathrm{a}}$ & $20,12 \pm 7,29^{\mathrm{a}}$ & $4,97 \pm 0,34^{\mathrm{a}}$ & $4,68 \pm 1,32^{\mathrm{a}}$ \\
TLG (mm) & $4,66 \pm 1,82^{\mathrm{a}}$ & $4,21 \pm 2,13^{\mathrm{a}}$ & $0,44 \pm 0,15^{\mathrm{a}}$ & $0,37 \pm 0,15^{\mathrm{a}}$ \\
ADG (mm/day) & $0,66 \pm 0,03^{\mathrm{a}}$ & $0,58 \pm 0,03^{\mathrm{a}}$ & $14,75 \pm 6,40^{\mathrm{a}}$ & $13,24 \pm 7,24^{\mathrm{a}}$ \\
RGR (\%) & $33,52 \pm 8,94^{\mathrm{a}}$ & $32,83 \pm 8,75^{\mathrm{a}}$ & $1,94 \pm 0,93^{\mathrm{a}}$ & $1,91 \pm 1,68^{\mathrm{a}}$ \\
SGR (\%/day) & $8,23 \pm 5,19^{\mathrm{a}}$ & $8,16 \pm 5,08^{\mathrm{a}}$ & $35,88 \pm 10,91^{\mathrm{a}}$ & $33,97 \pm 13,65^{\mathrm{a}}$ \\
\hline
\end{tabular}

$\mathrm{imL}$ (initial mean length), fmL (final mean length), TLG (Total length gain), CV (size variation coefficient), ADG (average daily gain), RGR (relative growth rate), SGR (specific growth rate), a: values in the same row with the same alphabetical letter are not significantly different $(\mathrm{P}>0.05)$.

Table 2. Parameters of linear growth according to developmental stage and hormone type

\subsection{Evolution of the total length of Clarias gariepinus according to the hormone type during the entire trial period}

Figure 1 shows the evolution of the total length of Clarias gariepinus during 70 days of breeding. It shows that this evolution was similar regardless of the hormone type $(\mathrm{P}>0.05)$. However fish from females treated with Ovaprim showed higher values than those of pituitary extracts, but not statistically different $(\mathrm{P}>0.05)$.

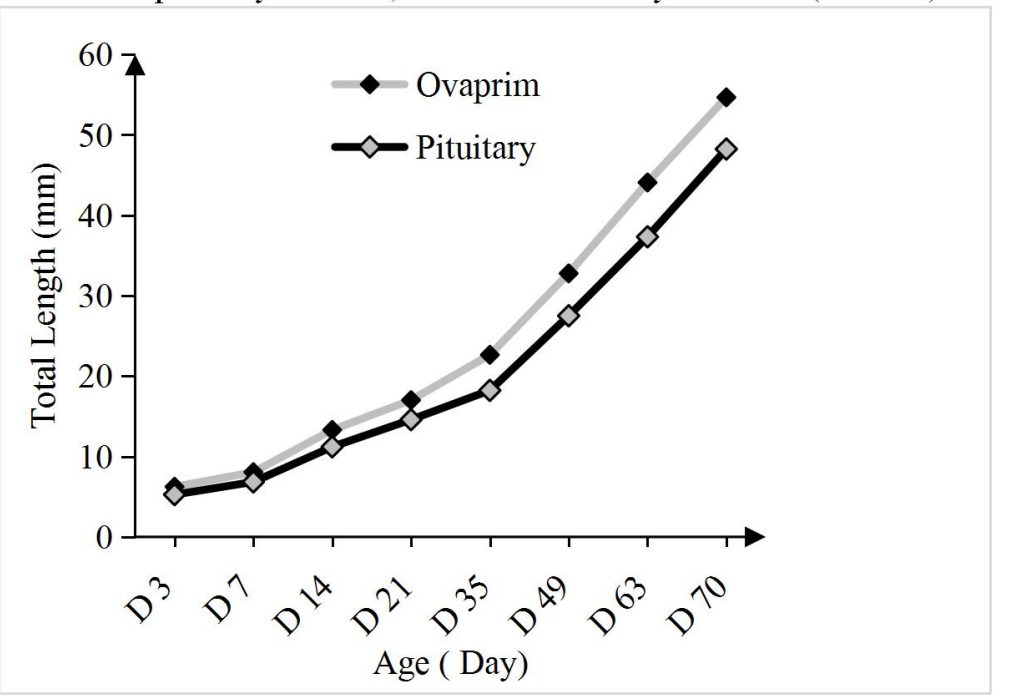

Figure 1; Evolution of the total length of Clarias gariepinus according to the hormone type during 70 days of breeding. 3.3 Survival rate and mass growth performances of Clarias gariepinus by developmental stage and of hormone type 
Survival rate and weight gain performances of Clarias gariepinus by hormone type and stage of development as presented in Table 3, show that: The survival rate was higher in larvae from the females induced with pituitary extracts compared with those from females induced to ovaprim whatever the stage of development considered. However, these differences were not significant $(\mathrm{P}>0.05)$ between treatments. Fish treated with Ovaprim hormone, had the highest mass growth performances compared to those treated with pituitary extracts, but not significantly $(\mathrm{P}>0.05)$.

\begin{tabular}{|c|c|c|c|c|}
\hline \multirow[t]{3}{*}{ Parameters } & \multicolumn{4}{|c|}{ Developmental stage } \\
\hline & \multicolumn{2}{|l|}{ Fry (D3 - D21) } & \multicolumn{2}{|c|}{ Fingerlings (D21 - D70) } \\
\hline & Ovaprim & Pituitary extracts & Ovaprim & Pituitary extracts \\
\hline SR (\%) & $58,24 \pm 11,47^{\mathrm{a}}$ & $65,13 \pm 19,34^{\mathrm{a}}$ & $67,67 \pm 18,49^{\mathrm{a}}$ & $72,39 \pm 13,38^{a}$ \\
\hline imW (mg) & $23,70 \pm 3,21^{\mathrm{a}}$ & $17,71 \pm 6,61^{\mathrm{a}}$ & $483,87 \pm 39,92^{\mathrm{a}}$ & $171,64 \pm 18,49^{\mathrm{a}}$ \\
\hline $\begin{array}{l}\text { fmW (mg) } \\
\text { WG (mg) }\end{array}$ & $\begin{array}{l}483,87 \pm 194,92^{\mathrm{a}} \\
230,87 \pm 5,16^{\mathrm{a}}\end{array}$ & $\begin{array}{l}171,64 \pm 120,49^{\mathrm{a}} \\
168,25 \pm 4,8^{\mathrm{a}}\end{array}$ & $\begin{array}{l}4137,28 \pm 388,51^{a} \\
483,31 \pm 128,37^{a}\end{array}$ & $\begin{array}{l}3253,63 \pm 230,94^{a} \\
382,10 \pm 75,31^{\mathrm{a}}\end{array}$ \\
\hline ADG (mg/day) & $32,92 \pm 7,86^{\mathrm{a}}$ & $23,97 \pm 3,64^{\mathrm{a}}$ & $69,48 \pm 31,23^{\mathrm{a}}$ & $54,52 \pm 25,02^{\mathrm{a}}$ \\
\hline RGR (\%) & $378,30 \pm 143,91^{\mathrm{a}}$ & $361 \pm 152,30^{\mathrm{a}}$ & $58,81 \pm 31,75^{\mathrm{a}}$ & $55,77 \pm 29,72^{\mathrm{a}}$ \\
\hline SGR (\% / day) & $21,63 \pm 7,83^{\mathrm{a}}$ & $19,67 \pm 4,57^{\mathrm{a}}$ & $5,23 \pm 2,01^{\mathrm{a}}$ & $5,06 \pm 1,27^{\mathrm{a}}$ \\
\hline $\mathbf{f N}$ & $13977 \pm 2456,54^{\mathrm{a}}$ & $17440 \pm 2178,63^{\mathrm{a}}$ & $10810 \pm 1857,95^{\mathrm{a}}$ & $13908 \pm 1158,46^{\mathrm{a}}$ \\
\hline
\end{tabular}

SR (Survival Rate), imW (initial mean Weight), fmW (final mean Weight), WG (Weight Gain), ADG (Average Daily Gain), RGR (Relative Growth Rate), SGR (Specific Growth Rate) and $\mathrm{fN}$ (final Number of fish). a: values in the same line with the same alphabetical letter are not significantly different $(\mathrm{P}>0.05)$.

Table 3. Survival and weight growth performance of Clarias gariepinus by the developmental stage and hormone type 3.4 Evolution of the average weight of Clarias gariepinus according to the hormone type in $\mathbf{7 0}$ days of breeding

Figure 2 shows the evolution of the average weight of Clarias gariepinus according to the hormone type and the breeding period. It appears that, whatever the hormone considered, the evolution is comparable ( $P>0.05)$. However, fish treated with Ovaprim showed higher mean weights than fish treated with pituitary extracts but not significantly (P> $0.05)$.

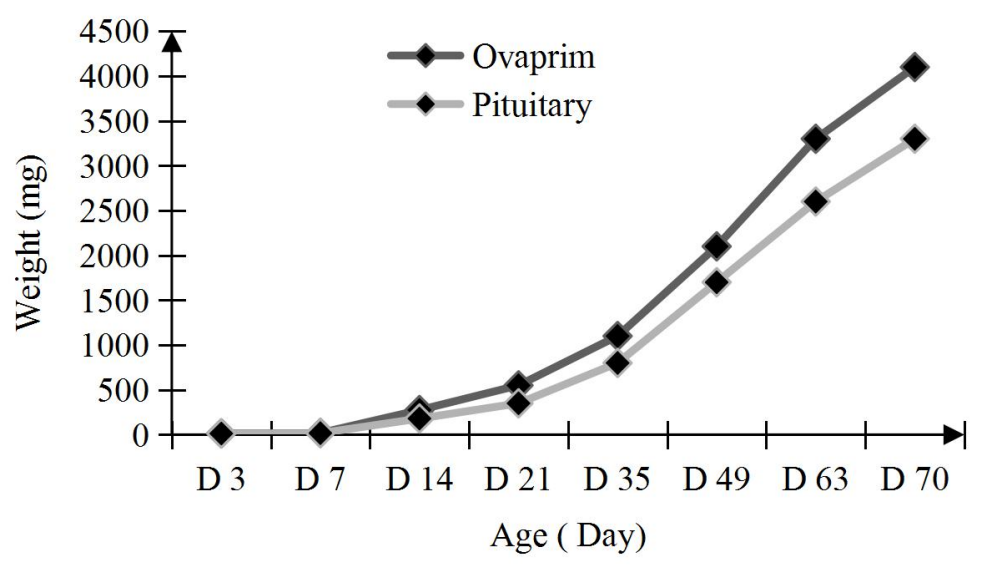

Figure 2; Evolution of the mean weight of Clarias gariepinus according to the hormone type during 70 days of breeding.

\subsection{Effect of the hormone type on weight-length relationship, growth type and condition factor $K$}

Table 4 illustrates, the parameters of the total weight / total length relationship depending on hormone type, growth type and condition factor $\mathrm{K}$ in Clarias gariepinus after 70 days of rearing. It shows that the coefficient of determination was significantly higher $(\mathrm{P}<0.05)$ on both types of hormones. However, it was comparable $(\mathrm{P}>$ $0.05)$ between them. The values of the allometric coefficient $b$ were significantly $(\mathrm{P}<0.05)$ lower than the isometric value $(\mathrm{b}=3)$ in all the fish, whatever the type of hormone considered. Condition factors $\mathrm{K}$ were $<1$ and comparable $(\mathrm{P}>$ 
$0.05)$ between the two hormones.

The evolution of the $\mathrm{K}$ factor during rearing (Figure 3) shows that larvae from females induced with pituitary extracts were significantly $(\mathrm{P}<0.05)$ more in shape compared to those from females induced with ovaprim at the fry stage. A significant decrease in $\mathrm{K}$ factor was recorded on the $21^{\text {st }}$ day of breeding regardless of hormone type. During the entire rearing period, the $\mathrm{K}$ factor has evolved sawtooth tending to decline whatever the type of hormone.

\begin{tabular}{|c|c|c|c|c|c|c|c|c|}
\hline \multirow[b]{2}{*}{ Hormone type } & \multicolumn{6}{|c|}{ LWR Parameters } & \multirow[b]{2}{*}{ GT } & \multirow[t]{2}{*}{ K Factor } \\
\hline & $\mathbf{N}$ & $\mathbf{r}^{2}$ & Equation & $\mathbf{a}$ & b & ts & & \\
\hline Ovaprim & 90 & 0,90 & $\mathrm{TW}=0,24 \mathrm{LT}^{2,47}$ & $0,24^{*}$ & $2,47^{*}$ & 0,29 & $\mathrm{~A}^{-}$ & $0,76 \pm 18^{*}$ \\
\hline Pituitary extracts & 90 & 0,92 & $\mathrm{TW}=0,27 \mathrm{LT}^{2,43}$ & $0,27^{*}$ & $2,43^{*}$ & 0,24 & $\mathrm{~A}^{-}$ & $0,67 \pm 32^{*}$ \\
\hline
\end{tabular}

Table 4. Weight-length relationship and condition factor $\mathrm{K}$ in Clarias gariepinus fry under 70 days of rearing

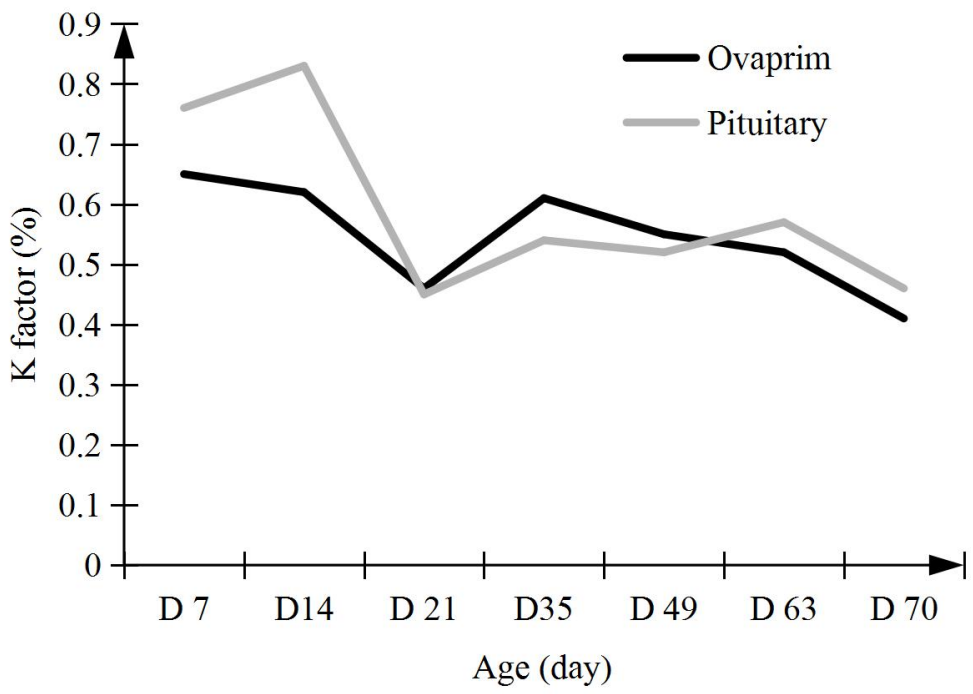

Figure 3; Evolution of the condition factor K according to the hormone type during 70 days of breeding.

\section{Discussion}

High survival $(>55 \%$ ) recorded at the fry stage in all treatments, could be due to the variation of the physicochemical parameters of the rearing water in the intervals required for the growth of Clarias gariepinus $\left(\right.$ Temperature $\left.=27.65 \pm 0.37^{\circ} \mathrm{C}, \mathrm{pH}=7.34 \pm 0.22, \mathrm{NO} 2-=0.24 \pm 0.006, \mathrm{NH} 4+=0.03 \pm 0.008\right)$. According to ${ }^{[3]}$, these values are similar to those commonly observed in this species at this stage of development in a controlled environment. Also, these results are better than those reported by ${ }^{[6]}$ after 17 days in hapa (35.5 to 64.8\%). At the juvenile stage, the survival rate remained low $(<75 \%)$ compared to the results generally reported under controlled conditions in this species: ${ }^{[3]}(80 \%)$ in the same species subjected to an optimal diet after 52 days of breeding; ${ }^{[19]}(70$ à $96 \%)$ and ${ }^{[20]}(95$ à $97.66 \%$ ) reported in Nigeria respectively in hapas and concrete tanks in six strains of the same species. This could be due to cannibalism, well known in this species ${ }^{[18]}$. However, these results are higher to those of ${ }^{[18]}: 26$ à $39 \%$ and ${ }^{[6]}$ : 31.25 to $44.16 \%$ reported respectively for the hormone Ovaprim in water recycle system and hCG in hapas for this species. The number of animals obtained at the end of breeding was higher for the pituitary extracts compared to Ovaprim. These results simply show that the synthetic hormone is not essential in this context, especially since it is very expensive.

In general, weight and linear growth performances recorded for Ovaprim are similar to those of ${ }^{[21]}$, in C. gariepinus strains induced with Ovaprim and pituitary extracts of males and females of the same species. According to $^{[22]}$, these results could be explained by the fact that the hormones express correlation effects with the growth of the animal, in other words that: for each hormone, there are chemical promoters or inhibitors associated with the growth of the animal and which depend on the dose of the hormone. The relative growth rate recorded in linear growth show 
according to ${ }^{[16]}$ that fish gain approximately $33 \%$ in 17 days at the fry stage and $14 \%$ in 70 days at the juvenile stage. According to the same authors in weight growth, fish gain approximately $378 \%$ of their initial weight in 17 days (fry stage) and $58 \%$ of their initial weight at the juvenile stage in 70 days. These results could mean that animals grow much faster at the fry stage than at the juvenile stage.

However, the average weights and total lengths obtained in this work at the juvenile stage for both types of hormones are lower than those reported by other authors: $9 \mathrm{~g}$ after 70 days in a closed circuit ${ }^{[3]} ; 8.88-10 \mathrm{~g}$ and $10 \mathrm{~cm}^{[23]}$. These differences could be due to high stocking densities during rearing (20 fry / 1); and (5000 then $3000 / 1)$ during the juvenile phase, because of the lack of space. The slowdown in growth could also be explained by the drop in $\mathrm{pH}(6.24 \pm$ 0.24) recorded during the 4th and 5th weeks of rearing, resulting in reduced feed intake, enrichment of water with organic waste and elevated nitrites and ammonium levels $(0.30 \pm 0.004 \mathrm{mg} / 1$ and $0.3 \pm 0.003 \mathrm{~m} / 1$ respectively). Size heterogeneity recorded for both types of hormone was low $(<36 \%)$ compared to ${ }^{[18]}$ in recycle water: 77.05 à $160.21 \%$. These results could be explained by the calibrations that took place every two weeks, to reduce the aggression of larger fish on smaller. Although treatment with Ovaprim expressed growth performance superior to that of pituitary treatment, the number of fish obtained at the end of the test was higher for the latter hormone. This number was significantly higher than that reported by ${ }^{[18]}$, in closed circuit in ponds with a volume of $1.5 \mathrm{~m}^{3}$, ie 2,572 fry of $4.03 \mathrm{~g}$, after a 38-day rearing cycle. In addition, the total length was strongly correlated $\left(\mathrm{R}^{2}>0.9\right)$ with the weight of the fish in both treatments. These results are similar to those reported in Clarias gariepinus and its hybrids (0.87-0.99) induced with the hormone Ovaprim and pituitary extracts of males of the same species ${ }^{[21]}$. The values of the regression coefficient $b$ are comply with those usually reported in the literature: 2.50 to $3.50^{[17]}$. Thus, according to ${ }^{[24]}$ specimens in this study showed negative allometric growth, thus the growth is in favor of the length. Condition factor $(K<1)$ shows that the fish were not overweight during the test. These results could be explained by the stress experienced by the animals during control fisheries, calibration manipulations and counting during the test. This stress is strongly expressed in the evolution of the $\mathrm{K}$ factor which decreases throughout the test. However, these results are similar to those reported in hybrids of Heterobranchus longifilis and Heterobranchus bidorsalis in a controlled system ${ }^{[25]}$. and those reported by ${ }^{[21]}$, in the same species induced with the same types of hormones.

\section{Conclusion}

A the end of this study on the survival and growth performance of Clarias gariepinus fry based on two types of hormone (fish pituitary extracts and the synthetic hormone Ovaprim) in recycled water in Akak Essatolo Fish Farm in South Cameroon. The main conclusions are:

The survival rate was better with the pituitary gland throughout the duration of the test. The number and biomass of fish produced were higher for fish from pituitary treatment, compared to those from Ovaprim

Ovaprim-treated specimens showed the best growth performance compared to those treated in the pituitary gland; but not significantly. Regardless of the type of hormone, the relative growth rate has shown that fish grow much faster at the juvenile stage than at the juvenile stage in both linear and weight growth. The weight / length relationship showed a significant correlation between the two parameters $\left(R^{2}>0.9\right)$. The coefficient of allometry $b$ was $<3$ regardless of the type of hormone considered, thus showing negative allometric growth.

The condition factor $\mathrm{K}$ was $<1$ and evolved in a decreasing fashion throughout the breeding period. Although the treatment with Ovaprim expressed growth performance superior to that of the pituitary treatment, the number of animals obtained at the end of breeding was higher for the latter.

It was recommended the use of pituitary extracts which not only are less expensive, but allow the production of high quantities of fish, because they recorded high survival rates compared to ovaprim.

\section{Author Contributions}

This work was carried out in collaboration between all authors. Author CTT designed the study, wrote the protocol and the first draft of the manuscript, and managed the analyses of the study. Author AEAD collected data, performed the 
statistical analysis. All authors managed the literature searches, read and approved the final manuscript.

\section{Conflict of Interest}

No conflict of interest was reported by the authors.

\section{Acknowledgments}

Authors warmly thank Mr. EDIMA NDJANA YANA NATHANAEL, head of Akak Essattholo Fish Farm for e reception and the provision of equipment necessary for the accomplishment of this work.

\section{Reférences}

1. FAO. Situation de l' aquaculture au Cameroun, vue générale du secteur aquacole national. Rome 2004; 9 p.

2. Tiogué TC, Kendi NFS, Tekou G, et al. Compensatory responses of Cyprinus carpio (Linnaeus, 1758) fry under different feed-deprivation regimes in happas in the Westhern-Cameroon; Annual Research \& Review in Biology 2017; 17(3):1-11. Doi:10.9734/ARRB/2017/36559

3. Ducarne CH, Micha JC. Technique de production intensive du poisson-chat africain, Clarias gariepinus. Tropicultura 2003; 21(4): 189-198.

4. Nguenga D. Partial gonadectomy in the catfish Heterobranchus longifilis (Teleostei, Clariidae): Regeneration time, quality and quantity of postsurgical sperm production. The Israeli journal of Aquaculture-Bamidgeh 2000; 52, (4): $167-172$.

5. Micha JC. La reproduction artificielle du Clarias africain. Vidéo, $15 \mathrm{mn}$. Artificial reproduction of african catfish. CIME, FUNDP, Namur, Belgium 2001.

6. Tiogue TC. Reproduction et croissance de deux souches sauvages et domestiques du poisson chat africain Clarias gariepinus (Burchell, 1822) et de leurs croisés. Thèse de Master of science en biotechnologie et production animale. FASA, UDs, 2006; 88 P.

7. http://neoindependance.canalblog.com/archives/2016/06/28/34024094.html

8. MINEPIA (Ministère de l' Elevage, des Pêches et des Industries Animales). Document de politique du Minepia Yaoundé 2013; 29 p.

9. http://neoindependance.canalblog.com/tag/Agropole .

10. FAO. Rapport panorama I sur les statistiques agricoles et alimentaires. Cameroun. CountryStat pour l' Afrique Sub-Saharienne. Rome 2009; 178 p.

11. Bomba OL. Caractérisation des fermes piscicoles dans la zone forestière du centre : cas du département du Mfoundi. Mémoire d' ingénieur Agronome, Faculté d'Agronomie et des Sciences Agricoles (FASA), Université de Dschang 2016; 70p.

12. Belinga SLR. Caractérisation socio-économiques et techniques de la pisciculture dans la Mvila, région du Sud-Cameroun. Mémoire d' ingénieur Agronome, Faculté d' Agronomie et des Sciences Agricoles (FASA), Université de Dschang $2017 ; 81 \mathrm{p}$

13. https://www.google.com/maps/place/Ebolowa/

14. Ambela EAD. Contribution à l' amélioration de la capacité de production d' alevins de Clarias gariepinus (Burchell, 1822) d' une écloserie en circuit fermé de la zone Sud-Cameroun. Mémoire d' ingénieur Halieute, Institut des Sciences Halieutiques à Yabassi (ISH), Université de Douala, Cameroun 2016; 94p

15. Yakubu AF, Nwogu NA, Olaji ED, et al. Impact of Three-different Commercial Feed on the Growth and Survival of Clarias gariepinus Burchell, 1822 Fry in Aquaria Glass Tanks. American Journal of Experimental Agriculture 2015; 9(1): 1-6.

16. Lugert $\mathrm{V}$, Thaller $\mathrm{G}$, Tetens $\mathrm{J}$, et al. A review on fish growth calculation: multiple functions in fish production and their specific application. Reviews in Aquaculture 2016; 8:30 - 42.

17. Tiogué TC, Zango P, Efolé ET, et al. Monthly Frequency Occurrence, Sex-ratio, Length/weight Relationship and Condition Factor of Native Fishes Caught in a Tropical Floodplain Rivers of Cameroon, Central Africa. Journal of Scientific Research \& Reports 2014; 3(22):2864-2874. Available : www.sciencedomain.org

18. Rukera TS, Micha JC, Ducarne C. Essais d' adaptation de production massive de juvéniles de Clarias gariepinus en conditions rurales. Tropicultura 2005; 23(4): 231-244.

19. Megbowon I, Fashina-Bombata AH, Akinwale AMM, et al. Growth performance of Wild Strains of Clarias gariepinus from Nigerian Waters. Journal of Fisheries and Aquatic Science 2014; 2014. Doi: 10.3923/JFAS.2014.

20. Olukunle O. The growth performance and survival of Clarias gariepinus fly raised in homestead concrete tanks. Journal of Fisheries and Aquatic Science 2013; 8(1):243-247 DOI:10.3923/jfas.

21. Ndimele EP, Owodeine GF. Comparative Reproductive and Growth Performance of Clarias gariepinus (Burchell, 1882 ) and Its Hybrid Induced with Synthetic Hormone and pituitary Gland of Clarias gariepinus. Turkish Journal of Fishries and Aquatic Sciences 2012;12:619-926

22. Nwokoye, Ononuju C, Nwuba, et al. Induced propagation of African clariid catfish, Heterobranchus biborsalis 
(Geoffrey saint Hilairie, 1809) using synthetic and homoplastic hormones. African journal of Biotechnology Vol. 6 (23). Department of Zoology, Nnamdi Azikiwe University 2007; 7 p.

23. Viveen WJAR, Richter CJJ, Van Oordt PGWJ, et al. Manuel pratique de pisciculture du poisson-chat africain (Clarias gariepinus). Direction générale de la coopération internationale du Ministère des Affaires Etrangères, Den Haag, The Netherlands 1985; 108p.

24. Tiogué TC, Tomedi ETM, Nguenga D, et al. Caracteristiques de morphologie générale et de croissance du Cyprinidae africain Labeobarbus batesii dans la plaine inondable des Mbô, Cameroun. Int. J. Biol. Chem. Sci. 2010; 4(6): 1988-2000. Available online at http://www.ajol.info/index.php/ijbcs

25. Kouassi EK. Contribution a une amélioration de la production aquacole en côte d' ivoire par hybridation de deux espèces de silure africain: Heterobranchus longifilis et Heterobranchus bidorsalis. Thèse de docteur vétérinaire. Ecole Inter-Etats des Sciences et Medecine Veterinaires de Dakar (EISMV) 2007;104 p. 